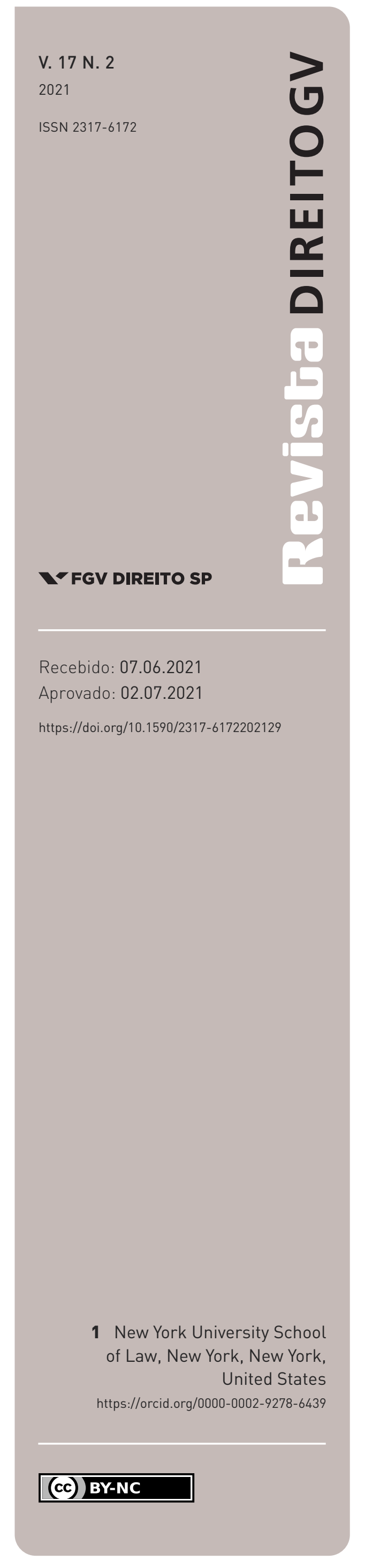

\title{
Anti-corruption Law and Systemic Corruption: The Role of Direct Responses
}

\author{
ANTICORRUPÇÃO E CORRUPÇÃO SISTÊMICA: O PAPEL DAS RESPOSTAS DIRETAS
}

Kevin E. Davis ${ }^{1}$

\begin{abstract}
Recent discussions of systemic corruption have cast doubt on the effectiveness of direct legal responses, that is to say, responses that involve the enforcement of explicit legal prohibitions on corrupt activity. This article argues that there are sound reasons to believe that anti-corruption law can play an affirmative role in controlling systemic corruption, but the advantages and disadvantages of alternative legal responses are likely to vary depending on both the preferred evaluative criteria and the context. This analysis is based on the premise that corruption becomes systemic when it is widespread, persistent, subversive, structural, or normalized. There are three general ways in which law enforcement agencies might respond to these forms of corruption: an enhanced effort ("big push enforcement"), get more agencies involved ("institutional multiplicity"), and win over the general public by confront powerful actors using tactics such as communication strategies ("political engagement"). Although each of these responses has limitations and dangers, they also have potential advantages. Thus, to entirely dismiss direct legal responses to systemic corruption appears to be a misguided response.
\end{abstract}

\section{Keywords}

Anti-corruption law; systemic corruption; institutional multiplicity; big push; legitimacy.

\section{Resumo}

Discussões recentes sobre corrupção sistêmica lançaram dúvidas sobre a eficácia das respostas jurídicas diretas, ou seja, respostas que envolvem a aplicação de proibições legais explícitas à atividade corrupta. Este artigo argumenta que há boas razões para acreditar que o direito anticorrupção pode desempenhar um papel positivo no controle da corrupção sistêmica, mas as vantagens e as desvantagens das respostas jurídicas alternativas tendem a variar de acordo com os critérios de avaliação escolhidos e com o contexto local. A análise tem como premissa a ideia de que a corrupção se torna sistêmica quando é generalizada, persistente, subversiva, estrutural ou normalizada. Existem três maneiras gerais em que as agências de aplicação da lei podem responder de maneira útil a essas formas de corrupção: esforço aprimorado (do tipo "big push", isto é, grandes investigações e punições), envolvimento de mais órgãos ("multiplicidade institucional") e enfrentamento de atores poderosos que utilizam estratégias de comunicação projetadas para conquistar o público em geral ("engajamento político"). Embora cada uma dessas respostas tenha limitações e perigos, elas também têm potenciais vantagens. Consequentemente, apelos para rejeitar respostas jurídicas diretas à corrupção sistêmica parecem equivocados.

\section{Palavras-chave}

Direito anticorrupção; corrupção sistêmica; multiplicidade institucional; big push; legitimidade. 


\section{INTRODUCTION $^{1}$}

The role of anti-corruption law in combating systemic corruption has shifted in recent years. Both empirical and theoretical analyses have cast doubt on whether the standard elements of anti-corruption law, namely, explicit legal prohibitions on corrupt activity enforced by impartial law enforcement agencies and courts, are effective responses to systemic corruption (MUNGIU-PIPPIDI, 2015; MUNGIU-PIPPIDI and DADAŠOV, 2017; UK DEPARTMENT FOR INTERNATIONAL DEVELOPMENT, 2015). Accordingly, some scholars now put much greater stock in indirect responses to the problem including responses that address social norms, state interventions in society, the allocation of power and responsibility across State branches, and/or the structure of political competition (ROTHSTEIN, 2018 and 2021; KHAN, ANDREONI and ROY, 2019). Some of these indirect responses to systemic corruption may be implemented through the legal system, but they do not have much to do with the standard elements of anti-corruption law, namely, prohibitions on corrupt activity enforced through criminal, civil, and administrative sanctions. In the past, proponents of "big bang" approaches to systemic corruption advocated both direct and indirect legal responses (see e.g. AIDT, 2003; BARDHAN, 2006; COLLIER, 2006; KINGSTON, 2008; KUPATADZE, 2013; ROSE-ACKERMAN, 1999), but new thinking almost completely dismisses a direct approach.

The fact that many scholars are turning away from direct legal responses to systemic corruption is remarkable given that anti-corruption law was prominent in the most famous successful accounts of controlling systemic corruption. In Hong Kong, the creation of the Independent Commission Against Corruption in 1973 is generally credited with eliminating the syndicates of police officers who previously plagued legal and illegal enterprises alike with extortionate demands (MANION, 2004). Similarly, the dramatic reduction of corruption in Singapore after 1960 also has been attributed in part to the creation of an independent anticorruption agency (QUAH, 1995). The anti-corruption strategies of both Hong Kong and Singapore famously included structural measures like paying civil servants high salaries. The conventional wisdom is that these cases continue to represent success stories for anti-corruption law. Cross-country empirical analysis suggests that the successes of Hong Kong and Singapore's independent anti-corruption commissions generally have not been replicated elsewhere (MUNGIU-PIPPIDI and DADAŠOV, 2017). However, more recent anti-corruption success stories also involved increased law enforcement, often in the form of increased monitoring and auditing (GANS-MORSE et al., 2018; PEIFFER and ARMYTAGE, 2019; TAYLOR, 2018).

1 Editors' note: This article was evaluated by two anonymous reviewers, guest editors Mariana Mota Prado and Marta Rodriguez de Assis Machado, and Catarina Helena Cortada Barbieri, the editor-in-chief of Revista Direito GV. 
The de-emphasis of anti-corruption law also reflects limited imagination about the theoretical potential of law as a means for social control. This recent intellectual shift is based in part on theoretical arguments that law enforcement is an inadequate response to systemic corruption. In a well-known series of articles, Rothstein and his collaborators have posited that systemic corruption ought to be conceptualized as a collective action problem rather than a principal-agent problem (PERSSON, ROTHSTEIN and TEORELL, 2013; ROTHSTEIN, 2018 and 2021). They argue that in these systemic corruption settings corrupt behavior patterns are sustained by large numbers of people, including enforcement officials, and will persist so long as a critical number of people believe that it will persist. Anti-corruption law is presumed to be a poor fit for collective action problems because it tends to focus on a small number of corrupt actors, depends on the initiative of incorruptible legal officials, and is conventionally understood to operate as a means of shaping incentives as opposed to shaping norms. This argument does not, however, take into account ways in which anti-corruption law might be refashioned to address collective action problems. Potential reforms include enhancements to the scale and efficiency of law enforcement; recruitment of additional agencies including foreign agencies; and deliberate efforts on the part of anti-corruption enforcement agencies to influence the norms around corruption.

The relative ease of reforming anti-corruption law as opposed to implementing indirect responses to systemic corruption provides another reason to continue exploring the potential of a direct approach. This may be why practitioners in societies afflicted by systemic corruption continue to devote time and energy to anti-corruption law. Initiatives such as Italy's Mani Pulite and Brazil's Operation Car Wash were explicitly designed to combat systemic corruption (LIMONGI, forthcoming). Research that questions the value of these initiatives is helpful; and as long as practitioners continue to resort to anti-corruption law in the face of systemic corruption, there is value in studying ways to make their efforts as worthwhile as possible.

This article offers a theoretical analysis of the role of anti-corruption law in combating systemic corruption. The conclusion is that there are sound reasons to believe that anti-corruption law can play an affirmative role in controlling systemic corruption, but the advantages and disadvantages of alternative legal responses vary depending on both the preferred evaluative criteria and the context. This analysis is premised on the idea that corruption becomes systemic when it is widespread, persistent, subversive, structural or normalized. Logic suggests that there are three general ways in which law enforcement agencies might usefully respond to these forms of corruption: an enhanced effort ("big push enforcement"), get more agencies involved ("institutional multiplicity"), and win over the general public by confronting powerful actors using tactics such as communication ("political engagement"). Although each of these responses has limitations and dangers, they also have potential advantages. Thus, entirely dismissing direct responses to systemic corruption appears to be a misguided response. 
To the extent it emphasizes the role of direct legal responses to systemic corruption the argument here is consistent with the views of scholars such as Cuéllar and Stephenson (2020), Rose-Ackerman and Palifka (2016, chapter 6), Rotberg (2017), and Taylor (2018), as well as anti-corruption NGOs such as Transparency International, who all continue to assign an important role to anti-corruption law in combating systemic corruption. The discussion of the advantages and disadvantages of alternative legal responses applies and extends the analytical framework developed in Davis (2019), and builds on ideas sketched in Davis (2012).

The first section of this article discusses several possible definitions of systemic corruption and argues that once the concept is properly understood there are clear reasons to deduce that anti-corruption law has a role to play in controlling it. The second section sets the stage for further discussion about anti-corruption law by defining its criteria for success. With this criteria in mind, the remaining sections explore in turn the merits of big push enforcement, institutional multiplicity, and political engagement. The overarching message is that the merits of any given measure will be highly context-specific (MARQUETTE and PEIFFER, 2019, p. 815-816) and depend upon not just prevailing patterns of corruption and the evaluative criteria applied, but also on the details of anti-corruption law that are often only discussed in specialized legal literature.

\section{i. Legal Responses to Systemic Corruption: An Overview}

\section{I. What Is Systemic CORRUPTION?}

The term "systemic corruption" is challenging to define. The problem does not stem from the term corruption. In legal settings corruption refers primarily to bribery and embezzlement, and the legal definitions of those terms are sufficient for the present purposes. The difficulty in defining systemic corruption lies in the word "systemic." According to its dictionary definition, the term refers to a feature of an entire system as opposed to just a part. This immediately gives rise to the question of what qualifies as a system. It seems clear that a country counts as a system, so we can meaningfully say, "corruption is systemic in Brazil." However, the concept also seems to apply to social units defined along other dimensions. For instance, we might say that corruption was systemic in the Hong Kong police force in the 1960s, or in the contemporary global mining industry.

There are also varying ways of interpreting what it means for corruption to be a characteristic of a system. The most basic definitions of systemic corruption focus on the distribution of corrupt transactions throughout the system. Used in these senses, systemic corruption is widespread and, possibly, persistent, means that corrupt transactions occur frequently in many distinct parts of the system and, perhaps, over a relatively long period of time.

The term systemic can also refer to the causes of corruption. For instance, it can mean, corruption that involves parts of a system that are specifically designed to control corruption. 
Alternatively, it might mean that corruption is caused by "structural" features of the system, meaning important features of a system besides those specifically designed to control corruption. Thus, instances of corruption that implicate anti-corruption enforcement agencies themselves would be examples of systemic corruption. Meanwhile, corruption caused by features of the rules or agencies that govern public procurement or the financing of elections in a particular society would qualify as structural forms of systemic corruption.

Finally, some definitions of systemic corruption incorporate the beliefs that participants in a system hold about corruption and the consequences of those beliefs. They focus on situations in which corruption is perceived to be widespread and is expected to be persistent (FISMAN and GOLDEN, 2017). These kinds of beliefs are in turn likely to be based on beliefs that corruption is structural or subversive. Belief-based definitions of systemic corruption focus on situations in which people believe that corruption is normalized, meaning that it is, or will be, the norm rather than the exception. There are several reasons to suspect that beliefs about norms influence behavior, including norms surrounding corruption (BICCHIERI, 2016). In particular, when corruption is normalized it is likely to be widespread and persistent. In other words, corruption may be a self-reinforcing phenomenon (see generally BARDHAN, 1997, p. 1330-1334; STEPHENSON, 2020). For example, people may believe that anti-corruption institutions have been so subverted that there is no benefit in attempting to punish corruption. Consequently, people generally have no incentive to refrain from corrupt behavior. The same outcome can occur if corruption becomes so prevalent that law enforcement agencies simply become overwhelmed or if the shame and stigma that would otherwise be associated with corruption disappears. Alternatively, if people believe that most public officials engage in corruption then honest people may avoid entering public service, either because they don't want their reputation to be tainted or because they wish to avoid the financial demands placed on public officials by family and friends. Finally, if people believe that corruption is widespread among bureaucrats they may decide that they have no choice but to pay bribes in order to obtain public services.

It is worth emphasizing that people's beliefs about corruption need not be grounded in objective reality (MORRIS, 2009, chapter 8). These sorts of beliefs are likely to be based on information obtained through social networks and social or mass media. Given the secretive nature of corruption, that information is unlikely to be reliable. We can also conjecture that popular beliefs about corruption will be biased towards the behavior of the elites, if only because their behavior tends to attract more media attention.

Although the definitions of systemic corruption listed above are conceptually distinguishable, they may not be distinguishable empirically. In fact, there are several intuitively plausible ways in which these features of corruption are likely to be causally related. We have already noted that normalized patterns of corruption may become widespread. We can also conjecture that widespread, inescapable and persistent patterns of corruption are likely to become normalized and subversive, and structural and subversive patterns of corruption 
are likely to be persistent. In many settings therefore, it will be useful to refer to systemic corruption incorporating these ideas as one without any further conceptual hairsplitting.

\section{I.2. The Role of Anti-Corruption LAW in Responding to Systemic Corruption}

Until recently, there appeared to be broad agreement among anti-corruption scholars and practitioners that controlling the forms of systemic corruption defined above might require a distinctive set of responses from anti-corruption law (see e.g., AIDT, 2003; BARDHAN, 2006; COLLIER, 2006; KINGSTON, 2008; KUPATADZE, 2013; ROSE-ACKERMAN, 1999 ; ROSE-ACKERMAN and PALIFKA, 2016). ${ }^{2}$ Naturally, to the extent that different forms of systemic corruption coincide, anti-corruption law presumably will deploy responses tailored to each form simultaneously. However, for the sake of analytical clarity it is useful to match different forms of systemic corruption with specific legal responses.

To begin, the fact that corruption is widespread or persistent implies that it is likely to overwhelm ordinary legal institutions and that some sort of extraordinary intervention will be required, such as an expansion of legal prohibitions or a "big push" on the part of law enforcement agencies (which I distinguish from a "big bang" that also involves structural reforms). A big push enforcement may involve either provision of additional resources for existing anti-corruption institutions, or improvements in the efficiency of these institutions. Alternatively, it might involve the recruitment of additional institutions, leading to what is known as "institutional multiplicity." To the extent that these institutions fail to secure adequate resources, enforcement agencies will have to resort to selective enforcement, which runs the risk of being perceived as politically biased.

Corruption that subverts key institutions in a society presents yet another type of challenge. Successful responses to subversive corruption will involve conflict with powerful actors. The key here is to ensure that anti-corruption enforcement agencies are not only immune to subversion but also sufficiently powerful to counter opponents who have captured other key institutions. Institutional multiplicity might also serve to limit the risk of subversion for several reasons. First, the more institutions there are, the more difficult it might be for corrupt actors to subvert them all (PRADO and PIMENTA, forthcoming). In addition, increasing the number of institutions might stimulate competition and facilitate benchmarking by overseers. These effects are likely to be particularly pronounced when institutional multiplicity involves institutions external to the relevant social unit.

The structural definition of systemic corruption points to structural reforms as the solution. Classic examples include introducing performance-based pay for civil servants, reducing

2 There is a separate debate about whether these responses should be undertaken all at once or in piecemeal. This article takes no position on that issue. For a recent intervention see Stephenson (2020). 
bureaucratic discretion, and increasing transparency in the financing of electoral campaigns (ROSE-ACKERMAN and PALIFKA, 2016, p. 126-160, 165-204 and 368). Structural reforms are beyond the scope of this paper. However, there are at least two ways that enforcement agencies can support structural reforms. First, they can target actors inclined to use corrupt means to thwart reforms. Second, they can serve as advocates for reform. Enforcement agencies that take these steps inevitably will become politically engaged, in the sense that their actions will be aimed at diminishing the political power of certain actors and those actors are likely to respond by challenging the power of the enforcement agencies. Enforcement agencies that attempt to promote structural reforms also are likely to become politically engaged in another sense: it will behoove them to develop strategies for communicating with and marshalling the support of large swathes of the general public. This kind of communication can serve as both a sword and a shield; it can be both a form of advocacy and protection against backlash from opponents of corruption reforms. Brazil's Operation Car Wash Task Force offers a classic example of a politically engaged enforcement agency. It not only targeted high-level political actors and proposed structural reforms, but also mounted a public relations campaign aimed at building public support for their initiatives (LAGUNES, 2020a and 2020b; LIMONGI, forthcoming).

Finally, if systemic corruption is defined by people's beliefs then the solution will have to involve changing those beliefs. There is no reason to presume that perceptions of corruption will always track objective facts and are immune to manipulation (MORRIS, 2009, chapter 8 ). It seems more reasonable to assume that expectations about how the law will be enforced will play a role in shaping beliefs about corrupt behavior (CHIAO, for thcoming; LAGUNES, 2021, p. 117). This provides another reason why responses to systemic corruption ought to include an explicit communication strategy, independent of efforts to support structural reforms.

\section{Criteria for the Evaluation of Anti-Corruption Regimes}

It is tempting to evaluate responses to systemic corruption purely in terms of their effectiveness in preventing corruption. Effectiveness in this sense is undoubtedly an important criterion for evaluating an anti-corruption regime. There are at least four other relevant criteria: efficiency, due process, fairness, and legitimacy (DAVIS, 2019).

The first additional criterion is efficiency, meaning the difference between the benefits and costs of any given version of a regime. Considering efficiency as opposed to just effectiveness means taking into account the costs as well as the benefits of anti-corruption law. This is important because putting the wheels of anti-corruption law in motion is expensive. To begin with there are the direct costs of enforcement, meaning the costs of dedicating investigators, prosecutors, courts, and correctional institutions to anti-corruption efforts as opposed to other socially beneficial activities. In addition, anti-corruption enforcement can 
impose substantial indirect costs on people and firms who are either targets of an investigation or have a stake in the welfare of the targets of an investigation. In complex cases involving multiple large organizations both the direct and the indirect costs of anti-corruption enforcement can be substantial.

The next criterion is "due process", which refers to an enforcement process that respects the rights guaranteed to defendants according to human rights norms. There is no general consensus on what due process requires in civil and administrative cases, where proceedings often place relatively modest burdens upon defendants and so correspondingly modest procedural safeguards are arguably required. There is, however, a consensus on what due process requires in criminal cases. The most basic rights are to, "a fair and public hearing by a competent, independent and impartial tribunal established by law" (INTERNATIONAL COVENANT ON CIVIL AND POLITICAL RIGHTS, Art. 14) and to:

: be presumed innocent until proven guilty;

: be informed promptly and in detail of the charge;

: adequate time and facilities to prepare a defense and to communicate with a counsel of one's choosing;

: $\quad$ be tried without undue delay;

: examine witnesses;

: not be compelled to testify against oneself or to confess guilt;

: a review of any conviction and sentence by a higher tribunal according to law; and

: not to be tried or punished again for an offence for which the person has already been finally convicted or acquitted (a principle embodied in legal doctrines variously known as non bis in idem, double jeopardy and res judicata).

Yet, another potentially relevant criterion is fairness. That is to say, we might ask whether the regime in question allocates the benefits and burdens of its operations fairly across and within societies. There are two broad conceptions of fairness: egalitarian and rights-based. Egalitarian conceptions of fairness hold that certain resources or, more commonly, opportunities to obtain certain resources or benefits, should be distributed equally to members of the relevant community (CANEY, 2001 and 2005). Regimes can be evaluated according to the extent to which they contribute to promote, or undermine the quest for equality. This 
includes asking whether the regime in question tends to exacerbate existing inequalities by creating extraordinary burdens or benefits for certain states, groups, or individuals. In contrast, rights-based conceptions of fairness pay special attention to the extent to which distributions of resources or opportunities allow every person to live a worthwhile life. This means that inequalities are tolerable so long as the regime does not cause anyone affected by its operations to fall below a minimum acceptable standard of living. That minimum is sometimes described as one that respects human rights (POGGE, 2008).

Last but not least, the anti-corruption regime should be evaluated in terms of its legitimacy, meaning the extent to which a person is justified in exercising coercive power over another person in a way that creates obligations of obedience, or at least support, for the other person. Legitimacy is relevant not only as an independent criterion for the evaluation of a regime but also as a possible determinant of effectiveness. There is considerable evidence that peoples' willingness to comply with and support a legal regime is positively influenced by their beliefs about its legitimacy.

There are many different views on the factors that enhance or detract from legitimacy and the weight to be given to those factors (PETER, 2017; DAVIS, 2019, p. 69-71). For instance, in some accounts, legitimacy depends exclusively on whether the regime in question produces beneficial consequences, which suggests that legitimacy does not operate as an independent criterion for evaluation (PETER, 2017, section 3.2). In this view, the legitimacy of anti-corruption laws and the agencies that enforce them will depend solely on whether they operate in ways that are effective, fair, and respectful of due process. A more conventional view is that the legitimacy of a regime depends on factors outside the outcomes that it generates (BUCHANAN and KEOHANE, 2006). In particular, it is common to associate legitimacy with specific characteristics of the decision-making process a regime follows. This includes whether people affected by the decision are entitled to participate, transparency, reason-giving, recourse or review, and legality (DAVIS, 2019).

The remaining sections of this article evaluate each of the three main categories of legal responses to systemic corruption - big push enforcement, institutional multiplicity, and political engagement - in light of not only their potential effectiveness, but also their compatibility with efficiency, due process, fairness, and legitimacy.

\section{Big Push Enforcement}

The merits of big push enforcement are likely to vary depending on a broad range of context-specific factors as well as which evaluative criteria are applied. The relevant contextual factors include: patterns of corruption in society, substantive and procedural rules that govern enforcement proceedings, and the precision with which the regime sanctions corrupt actors as opposed to the relatively innocent people around them. 


\section{3. i. Effectiveness of Big Push Enforcement}

There are several reasons to predict that enforcement actions aimed at systemic corruption will have far-reaching effects, particularly if they result in the imposition of meaningful sanctions on powerful actors. One school of thought focuses on the potential positive effects. First, challenging the impunity of high-ranking public officials and their collaborators in the private sector may serve to topple a corrupt elite and permanently alter the distribution of power in society. Second, these sorts of enforcement actions are likely to involve extraordinary legal measures that may have spillover effects on the rest of the legal system. Third, largescale operations aimed at elite targets may attract the attention of the media and, by extension, the general public. Popular attention may in turn translate into popular support for expansions of legal prohibitions, allocations of additional resources to enforcement agencies, and structural reforms.

There is room for skepticism about whether anti-corruption enforcement will have all these positive effects. To begin with there is concern about subversion. As proponents of indirect approaches frequently point out, if enforcement agencies themselves have been corrupted then a big push simply may not be feasible (PERSSON, ROTHSTEIN and TEORELL, 2013; ROTHSTEIN, 2018 and 2021; KHAN, ANDREONI and ROY, 2019). But subversion is not the only obstacle to effective anti-corruption enforcement. For instance, proceedings that topple one set of corrupt actors may merely make room for them to be replaced by another group. Expanded legal prohibitions or enhanced investigative powers and sanctions might be used by unaccountable enforcement officials to repress political opponents or marginalized groups rather than the most culpable corrupt actors. In addition, drawing attention to allegations of corruption can backfire. Corrupt political leaders may exploit the publicity associated with enforcement proceedings by using claims of persecution to rally their supporters. Unsuccessful enforcement actions can fuel beliefs that corruption is normalized and that corrupt actors can operate with impunity.

\subsection{Direct COSTS of LAW ENFOrCeMENT}

The costs of using increased enforcement to achieve any given level of success in combating systemic corruption will vary depending on the nature of the corruption. All other things being equal, the more widespread the corruption, the greater the costs of investigation and prosecution. Both the number of cases of wrongdoing and the number of people involved are significant here. If a small number of people play a critical role in a large portion of the misconduct then a relatively low level of investigative and prosecutorial effort (compared to the effort required if corruption is more widespread), combined with sufficiently stiff penalties, might go a long way toward preventing further misconduct.

The size of the gains from corruption is also relevant. The greater the criminal profits, the greater the incentive to invest in concealing them from enforcement agencies, for example, by holding assets offshore and through intermediaries. An actor who has earned substantial 
profits from corruption and is faced with the prospect of substantial penalties is likely to be both willing and able to mount a vigorous defense. In many situations, the greater the resources invested by the defense, the greater the resources that the prosecution will have to invest if it wishes to prevail.

The magnitude of enforcement costs depends in part on the substantive legal rules that determine what sort of evidence must be presented before sanctions can be imposed for corruption. Many legal systems permit such sanctions to be imposed even in the absence of proof of paradigmatic elements of bribery or embezzlement (DAVIS, 2019, chapters 6-8). For example, in cases of suspected bribery it may be enough to establish that something of value was offered or promised, without proof that value was received or any sort of official action was provided in return. Or public officials may be sanctioned for unexplained consumption, even in the absence of proof that their wealth was derived from misuse of their official position. Yet another tactic is to hold people or organizations liable for the misconduct of their associates, even in the absence of proof that they controlled or directed, or perhaps were even aware, of the conduct in question.

Procedural rules also can play a significant role in determining the direct costs of enforcement. Procedures that grant enforcement agencies broad authority to monitor and audit private actors with minimal oversight obviously reduce the costs of monitoring and investigation. Procedures that permit interim sanctions, such as detention or seizure of assets, to be imposed prior to trial, or after trial while appeals are pending, can reduce the burden upon enforcement agencies by diminishing the bargaining power and resources of defendants. Procedures that reduce the number of interlocutory appeals will naturally tend to reduce costs. The same is true of procedures that permit proceedings to be resolved through negotiation without going to trial. Inquisitorial procedures that reduce the amount of control that defendants have over the collection and presentation of evidence can reduce the impact of resource differentials.

Another dimension along which enforcement processes can vary is in the extent to which they are conducted by private as opposed to public actors. At the investigative stage this can involve allowing evidence collected by private firms to be used in subsequent proceedings. At later stages in the enforcement process private actors may be allowed to initiate and conduct proceedings, to adjudicate disputes (as in the case of arbitration), and to monitor compliance with sanctions. Permitting enforcement by private as opposed to public actors typically will shift enforcement costs from the state to private actors, especially if private action is mandatory rather than voluntary. Relying on private enforcement also has the potential to reduce aggregated enforcement costs. But whether that potential is realized or not depends on factors such as the relative expertise, integrity and levels of remuneration of public and private actors, as well as their relative propensities to engage in wasteful spending.

As Prado and Machado (forthcoming) document in their case study of Brazil's Operation Car Wash, big push enforcement can coincide with reforms to anti-corruption law 
along many or all of these substantive and procedural dimensions. These features of anti-corruption law will affect more than just the efficiency of big push enforcement. They will also affect its compatibility with due process. Procedures that provide for checks on infringements of privacy and fair trial rights by enforcement officials generally tend to be costly. Consequently, unless a high value is assigned to protect the interests of defendants, there may be tension between promoting efficiency and due process.

\subsection{Indirect COSTS OF LAW ENFORCEMENT}

Increased enforcement can also lead to costs being imposed upon people other than targets of the enforcement action. This is a particular concern when the target is an organization rather than an individual. Punishment aimed at the organization may harm all of its stakeholders, and those may include people with little connection to the misconduct that triggered the sanction. In the case of a corporation those stakeholders ordinarily will include employees, investors, customers and suppliers. Substantial financial penalties or structural constraints on the operations of corporations involved in corruption may have drastic effects on the wellbeing of all their stakeholders. At the same time, many of those stakeholders are unlikely to be capable of preventing corporate misconduct, either directly or by altering their dealings with high-risk firms in ways that encourage them to clean up their acts. Consequently, imposing these kinds of indirect costs is likely to be inefficient. The risk of inefficiency is particularly high when big push enforcement disables a large proportion of the firms in a given region, industry, or project and it is difficult for people and assets to be reallocated from sanctioned firms to unsanctioned firms.

There are ways in which legal rules can be designed to minimize the indirect costs of anticorruption enforcement. One way is to target individuals rather than organizations. Another way is to focus sanctions on the class of actors most likely to have control over the organization's compliance with anti-corruption norms, namely, the shareholders. In addition, the magnitude of penalties imposed on corporations can be reduced in cases where they threaten to cause significant collateral damage. Finally, it is worth noting that the magnitude of indirect costs will depend on bodies of law outside of anti-corruption law. Consider the question of whether imposing a financial penalty upon a corporation will harm anyone beyond its investors. That will depend on how easy it is for the assets of a corporation that is unable to fulfill its financial obligations to the government to be transferred to new owners without losing their value. That in turn will depend on both the depth of the market for corporate assets and the applicable insolvency regime.

\section{Institutional Multiplicity}

As noted above, a logical response to certain forms of systemic corruption is institutional multiplicity, that is to say, getting multiple agencies involved in the enforcement of anti-corruption 
law. ${ }^{3}$ Law enforcement is a process that involves several distinct activities: monitoring, investigation, adjudication (which includes prosecution, defense, and decision making), imposition of sanctions, and publicity (DAVIS, JORGE and MACHADO, 2021). The outputs generated in earlier stages, such as monitoring or investigation, typically serve as inputs in later stages, such as investigation or adjudication. It is not unusual for different agencies to be responsible for each of these activities, at least in the anti-corruption context, so enhancing institutional multiplicity usually refers to increasing the number of agencies responsible for the same type of enforcement activity (PRADO and CORNELIUS, 2020).

Institutional multiplicity can take many different forms (PRADO and CORNELIUS, 2020). Accordingly, it is worth considering the factors that influence the appeal of alternative institutional configurations.

\section{I. Advantages and Disadvantages of Institutional Multiplicity}

Institutional multiplicity has many advantages. As noted above, it can be a way of increasing the resources devoted to enforcement. Institutional multiplicity can also serve to allocate enforcement responsibilities to agencies which are either more efficient or which present less risk of subversion. In addition, by introducing competition and allowing for benchmarking institutional multiplicity can enhance efficiency and reduce the risk of subversion across an entire set of agencies.

The potential drawbacks of institutional multiplicity include: cost, conflict, undue burdens for defendants and diffusion of accountability. The potential for added costs is obvious; it is simply the flipside of attracting additional resources to anti-corruption enforcement. Whether expending additional resources on anti-corruption enforcement is an advantage or disadvantage of institutional multiplicity depends on whether those resources generate incremental gains in effectiveness or are simply redundant (JONES and PEREIRA NETO, forthcoming). Sometimes it will be most effective to deploy additional resources to a single institution in order to capture economies of scale rather than to spread them across multiple institutions.

Conflict arises when one agency's actions undermine the effectiveness of another agency. For instance, one agency might tip off the target of another agency's investigation and allow them to abscond before being prosecuted. Or an agency might refuse to honor another agency's promises of leniency, thereby undermining the second agency's effort to induce corrupt actors to cooperate in investigations. Still other forms of conflict arise when the cumulative sanctions imposed by agencies are either excessive or inadequate (see e.g. ARANHA, 2020; JONES and PEREIRA NETO, forthcoming). 
Multiplicity can also be extremely burdensome for defendants. Instead of facing the prospect of a single proceeding, institutional multiplicity can mean that a person faces the possibility of having to defend themselves in multiple fora over a long period of time. Defendants in that position may be so overwhelmed by the combined resources of the enforcement agencies arrayed against them that they are unable to mount an effective defense. Those defendants are at risk of becoming subject to unwarranted sanctions. The result can be characterized as either a compromise of the regime's effectiveness or a violation of due process.

Finally, when multiple agencies operate in a given domain it can be difficult to trace responsibility for outcomes to the actions of any particular agency. This in turn diminishes accountability and therefore can compromise legitimacy.

\subsection{Coordination Mechanisms and Institutional Modularity}

Both the advantages and disadvantages of institutional multiplicity depend on the extent to which the relevant agencies coordinate their actions. In this context, coordination entails working together to achieve common goals. Coordination may allow agencies to allocate enforcement tasks efficiently and avoid redundancy, but it also may be difficult to achieve and may re-introduce the kind of centralization that facilitates subversion.

The extent of coordination is shaped by what can be called coordination mechanisms, meaning norms that inhibit or facilitate coordination. Legal rules that define the 'jurisdiction' of enforcement agencies qualify as coordination mechanisms. Those jurisdictional rules commonly allocate responsibility over enforcement activities based on factors such as where the misconduct takes place or where the adverse effects are felt, the nationalities of the targets, or whether another agency has previously prosecuted the defendant. More sophisticated rules are framed in conditional terms. For example, a country's agencies might be given jurisdiction to prosecute any national it has refused to extradite (UNITED NATIONS CONVENTION AGAINST CORRUPTION, Art. 42(3)).

The design of coordination mechanisms can be a critical determinant of the ramifications of institutional multiplicity. Take, for example, the principle of ne bis in idem, which bars an agency from sanctioning someone who has previously been sanctioned by another agency. The principle can be implemented more or less broadly. The narrowest versions only give preclusive effect to prior proceedings that involved the same conduct, the same charge or civil claim, and the same parties. Broader versions expand the set of proceedings that will have preclusive effect along any or all these dimensions. The broader the principle the lower the risks associated with institutional multiplicity, such as redundancy, undermining promises of leniency, and violations of due process. At the same time, the broader version of the principles sacrifices some of the benefits of institutional multiplicity. For instance, broad application of the principle makes it relatively easy for defendants to subvert anti-corruption enforcement by colluding with a single enforcement agency to bring an enforcement action that yields a very modest penalty but precludes other agencies from 
punishment (see e.g., PRADO and PIMENTA, forthcoming). A narrower version of the principle, or a version that offers broad protection conditional on the bona fides of the prior proceeding, would offer more protection against subversion.

Moving to a higher level of generality, the effects of institutional multiplicity will depend on the extent to which anti-corruption institutions are capable of adjusting the extent to which they coordinate to reflect the prevailing circumstances. As Prado and Carson (2016) argue, there may be considerable merit in a system which incorporates multiple enforcement agencies that are able but not required to coordinate with one another. Davis, Jorge and Machado (2021) refer to this concept as "institutional modularity."

\subsection{FOREIGN InSTITUTIONS}

Increased reliance on enforcement agencies outside the affected society is often offered as a solution to systemic corruption. In practice this is accomplished by adopting legal rules which grant broad extraterritorial jurisdiction to enforcement agencies from foreign countries. Another approach is to rely, to some extent, upon enforcement by supranational bodies such as international financial institutions or the International Commission Against Impunity in Guatemala or the proposed International Anti-Corruption Court (WOLF, 2018).

This particular form of institutional multiplicity has distinctive advantages and disadvantages. As a general matter, the larger the set of agencies involved in anti-corruption enforcement the greater the likelihood of introducing agencies that are more efficient and less prone to subversion. It also seems plausible that the benefits of competition and benchmarking increase steadily with the number of agencies involved. Thus, allowing foreign enforcement agencies into the mix of agencies participating in anti-corruption enforcement may be a way of capturing a greater share of the benefits of institutional multiplicity, particularly in small communities. It also seems reasonable to assume that foreign agencies are typically less prone to subversion than local ones.

At the same time, if foreign agencies are defined to mean any agencies that are not politically accountable to the members of a particular community, then, by definition, their involvement in proceedings which affect the community in question raises concerns about legitimacy _ unless legitimacy is defined purely in terms of effectiveness.

In addition, allocating resources across jurisdictional boundaries is often more difficult than within those boundaries. As a result, the involvement of foreign agencies can make it difficult to redistribute the costs and benefits of enforcement actions in a fair manner. In practice, these issues arise when it comes to ensuring that fines, penalties, and forfeitures are used on the one hand to cover the costs of agencies that have contributed to the enforcement effort and on the other hand to compensate victims of corruption. The challenge is both to arrive at an agreement on how the resources should be allocated and to adopt legal mechanisms that enable redistribution of resources. Both tasks are more difficult to accomplish across borders than within them, especially when agencies do not trust one another. 


\section{Political Engagement}

As we have seen, there are several senses in which legal responses to systemic corruption might be characterized as 'political' in nature. First, they might advance the political fortunes of some groups rather than others. Second, they might involve conscious efforts to mobilize popular support for anti-corruption initiatives. Both these forms of political engagement raise concerns about effectiveness and legitimacy. We will consider these concerns separately. In practice though they may be interrelated because, as noted above, there is evidence that more legitimate enforcement agencies and actions are also more effective.

\section{I. EFFECTIVENESS}

One reason to be concerned about the effectiveness of politically engaged anti-corruption law enforcement stems from concerns about relative power. Efforts to use anti-corruption law against systemic corruption may trigger resistance from people who stand to lose resources and power. That resistance might go well beyond simply raising legal defenses in response to individual enforcement actions. First, the resistance might involve more people than just those targeted by enforcement agencies. Second, resistance could involve a broad range of tactics designed to undermine the power and legitimacy of enforcement agencies. For example, resistance might involve concerted efforts on the parts of both public officials and private actors who benefit from corrupt relationships to oust individual enforcement officials, cut off funding for anti-corruption enforcement operations, expand the scope of immunity from prosecution, subject prosecutors to sanctions for overstepping their bounds, etc. These concerns militate in favor of empowering enforcement agencies through legal guarantees of independence, including constitutional limits on termination and guarantees of funding.

The effectiveness of politically engaged anti-corruption law enforcement is also likely to depend on the expertise of enforcement officials. In most jurisdictions, police and prosecutors and correctional officials are not selected for their political skills, and development of those skills is not typically part of their formal training. We can conjecture, however, that enforcement agencies run by political appointees or elected officials will be less susceptible to this problem (TUSHNET, 2019, p. 454).

Even if training in political advocacy and persuasion was part of the enforcement agencies' training there would still be reason to be concerned about their effectiveness. Very little is known about how to craft effective communications strategies in this area. Consider, for instance, the questions of how an agency would persuade the public that corruption has declined, or better yet, that corruption has declined and the decline is attributable to the agency's efforts. Reliable data on the incidences of corruption - with the possible exception of data on solicitation of bribes from strangers - is difficult to obtain. Information about enforcement actions and their outcomes ought to be available to an enforcement agency, but it is difficult to know what inferences people will draw from the publication of 
that information and whether they will all draw the same inferences. ${ }^{4}$ News of a surprising increase in convictions for corruption might be taken as a sign of progress and an indication that corrupt actors have either been incapacitated or deterred. Alternatively, it might be interpreted as a sign that corruption is more prevalent than recipients of the news suspected (PEIFFER, 2018; CHEESEMAN and PEIFFER, 2020), or that a temporary enforcement push is likely to be followed by a decline in enforcement and a corresponding rise in the level of corruption. There is evidence that even within the same society the impact of any given communication depends on characteristics of both the audience and the message (CHEESEMAN and PEIFFER, 2020). But evidence on all these points is limited. This suggests that advocacy and persuasion on the part of enforcement agencies is more of an art than a science.

\subsection{LEGITIMACY}

Politically engaged anti-corruption law enforcement also raises serious concerns about legitimacy. The most obvious concern is about democratic accountability. In a democratic system there is a strong argument to be made that dramatic changes in political power should be undertaken democratically, either through the electoral system or by democratically elected representatives. This principle weighs in favor of sanctioning elected officials through impeachment rather than prosecution. Concerns about accountability also go against efforts to maximize the independence of enforcement agencies (TUSHNET, 2019, p. 447). Finally, concerns about legitimacy weigh in favor of structural reforms driven by elected officials as opposed to unaccountable enforcement officials.

The legitimacy of politically engaged anti-corruption enforcement may be bolstered by practices such as open public consultations about enforcement policies. There may, however, be a tension between transparency and effectiveness. For example, transparency about resource constraints or rates of corruption detection $=$ will tend to compromise deterrence if potential wrongdoers otherwise would have overestimated their chances of being caught and punished.

\section{CONCLUSION}

This article seeks to define and highlight the key role of anti-corruption law as a response to systemic corruption. It reflects three reactions to this tendency.

First, law can play a role in controlling systemic corruption. Systemic corruption can take several different forms, but even taking into account those variations, theory suggests

$4 \quad$ It may not even be clear what inferences people should draw from limited data about the effectiveness of anti-corruption law (DAVIS, forthcoming). 
that three broad types of law enforcement strategies generally merit consideration as responses to systemic corruption: big push enforcement, institutional multiplicity, and political engagement.

Furthermore, legal interventions ought to be evaluated in terms of more than just their effectiveness in controlling corruption. Even if we accept the premise that corruption is a problem that does not mean that it ought to be tackled at all costs. Some sort of weighing of costs against benefits is warranted. The economic costs can be incorporated by evaluating anti-corruption law in terms of efficiency as well as effectiveness. Other types of costs can be captured by considering criteria such as due process, legitimacy, and fairness. This multifaceted evaluative framework can be extended to examine whether, over the long term, aspects of anti-corruption law risk compromising broader values such as economic growth, democracy, and respect for human rights.

Finally, anti-corruption law is a complex phenomenon, in the sense it can vary along many dimensions. The potential variations include domains often overlooked by social scientists who theorize on a global scale about broadly defined concepts like "corruption." As it turns out, there is considerable room for variation in the details of anti-corruption law, including: rules that determine what counts as sanctionable misconduct; rules that define the jurisdiction, funding and staffing of enforcement agencies; procedural rules that govern enforcement actions; and rules on how the burdens of sanctions are distributed among people connected with corrupt activity. The ultimate impact of anti-corruption law is likely to be influenced by variations along these dimensions, as well as the context in which it operates.

These findings suggest that it is worthwhile for social scientists to continue to investigate the role that anti-corruption law might play in controlling systemic corruption.

\section{ACKNOWLEDGMENTS}

The author would like to thank Paul Lagunes, Mariana Prado and Raquel Pimenta for their helpful comments on an earlier draft. Financial support from Filomen D'Agostino and Max E. Greenberg Research Fund at the NYU School of Law is gratefully acknowledged. 


\section{REFERENCES}

AIDT, Toke S. Economic Analysis of Corruption: A Survey. Economic Journal, v. 133, n. 491, p. F632F652, 2003.

ARANHA, Ana Luiza. Lava Jato and Brazil's Web of Accountability Institutions: A Turning Point for Corruption Control? In: LAGUNES, Paul; SVEJNAR, Jan (ed.). Corruption and the Lava Jato Scandal in Latin America. New York: Routledge, 2020.

BARDHAN Pranab. The Economist's Approach to the Problem of Corruption. World Development, v. 34, n. 2, p. 341-348, 2006.

BARDHAN, Pranab. Corruption and Development: A Review of Issues. Journal of Economic Literature, v. 35, n. 3, p. 1320-1346, 1997.

BICCHIERI, Cristina, Norms in the Wild: How to Diagnose, Measure and Change Social Norms. New York: Oxford University Press, 2016.

BUCHANAN, Allen; KEOHANE, Robert O. The Legitimacy of Global Governance Institutions. Ethics \&International Affairs, v. 20, n. 4, p. 405-437, 2006.

CANEY, Simon. Justice Beyond Borders: A Global PoliticalTheory. New York: Oxford University Press, 2005.

CANEY, Simon. Cosmopolitan Justice and Equalizing Opportunities. Metaphilosophy, v. 32, p. 113 $134,2001$.

CHEESEMAN, Nic; PEIFFER, Caryn. The Unintended Consequences of Anti-Corruption Messaging in Nigeria: Why Pessimists Are Always Disappointed. ACE Working Paper 024, 2020.

CHIAO, Vincent. Corruption and the Criminal Law: Assurance and Deterrence. University of Toronto Law Journal, forthcoming.

COLliER, Paul. African Growth: Why a 'Big Push'? Journal of African Economies, v. 15, n. 2, p. 188 $211,2006$.

CUÉLLAR, Mariano-Florentino; STEPHENSON, Matthew. Taming Systemic Corruption: The American Experience and Its Implications for Contemporary Debates. Working Paper. Cambridge: Harvard Public Law, 2020. 
DAVIS, Kevin E. The Limits of Evidence-Based Regulation: The Case of Anti-Bribery Law. University of Toronto Law Journal, for thcoming.

DAVIS, Kevin E. Between Impunity and Imperialism: The Regulation of Transnational Bribery. New York: Oxford University Press, 2019.

DAVIS, Kevin E. The Prospects for Anti-corruption Law: Optimists versus Skeptics. Hague Journal on the Rule of Law, v. 4, p. 319-336, 2012.

DAVIS, Kevin E.; JORGE, Guillermo; MACHADO, Maíra R. Coordinating the Enforcement of AntiCorruption Law: South American Experiences. World Comparative Law, v. 54, n. 2, p. 160-199, 2021.

FISMAN, Ray; GOLDEN, Miriam A. Corruption: What Everyone Needs to Know. New York: Oxford University Press, 2017.

GANS-MORSE, Jordan et al. Reducing bureaucratic corruption: Interdisciplinary perspectives on what works. World Development, v. 105, p. 171-188, 2018.

JONES, Alison; PEREIRA NETO, Caio Mário da Silva. Combatting Corruption and Collusion in Public Procurement: Lessons from Operation Car Wash. University of Toronto Law Journal, for thcoming.

KHAN, Mushtaq; ANDREONI, Antonio; ROY, Pallavi. Anti-corruption in adverse contexts: strategies for improving implementation. ACE Working Paper 013, 2019.

KINGSTON, Christopher. Social Structure and Cultures of Corruption. Journal of Economic Behavior and Organization, v. 67, n. 1, p. 90-102, 2008.

KUPATADZE, Alexander. Moving Away from Corrupt Equilibrium: 'Big Bang' Push Factors and Progress Maintenance. GEGWorking Paper 2013/85, Global Economic Governance Program, University of Oxford, 2013.

LAGUNES, Paul. The Eye \& theWhip: Corruption Control in the Americas. New York: Oxford University Press, 2021.

LAGUNES, Paul. An Interview with Daltan Dallagnol. In: LAGUNES, Paul; SVEJNAR, Jan (ed.). Corruption and the Lava Jato scandal in Latin America. New York: Routledge, 2020a. p. 113-128.

LAGUNES, Paul. An Interview with Sérgio Moro. In: LAGUNES, Paul; SVEJNAR, Jan (ed.). Corruption and the Lava Jato scandal in Latin America. New York: Routledge, 2020b. p. 129-140. 
LIMONGI, Fernando. From Birth to Agony: The Political Life of Car Wash (Lava Jato). University of Toronto Law Journal, forthcoming.

MAINWARING, Scott. Introduction: Democratic Accountability in Latin America. In: MAINWARING, Scott; WELNA, Christopher. Democratic Accountability in Latin America. New York: Oxford University Press, 2003. p. 3-30.

MANION, Melanie, Corruption by Design: Building Clean Government in Mainland China and Hong Kong. Cambridge: Harvard University Press, 2004.

MARQUETTE, Heather; PEIFFER, Caryn. Thinking Politically about Corruption as Problem-Solving: A Reply to Persson, Rothstein, and Teorell. Governance, v. 32, p. 811-820, 2019.

MORRIS, Stephen D. Political Corruption in Mexico: The Impact of Democratization. Boulder: Lynne Rienner Publishers, 2009.

MUNGIU-PIPPIDI, Alina. The Quest for Good Governance: How Societies Develop Control of Corruption. Cambridge: Cambridge University Press, 2015.

MUNGIU-PIPPIDI, Alina; DADAŠOV, Ramin. When Do Anticorruption Laws Matter? The Evidence on Public Integrity Enabling Contexts. Crime, Law \& Social Change, v. 68, p. 387-402, 2017.

PEIFFER, Caryn. Message received? Experimental findings on how messages about corruption shape perceptions. British Journal of Political Science, v. 50, n. 3, p. 1207-1215, 2018.

PEIFFER, Caryn; ARMYTAGE, Rosita. Searching for Success: A Mixed Methods Approach to Identifying and Examining Positive Outliers in Development Outcomes. World Development, v. 121, p. 97-107, 2019.

PERSSON, Anna; ROTHSTEIN, Bo; TEORELL Jan. Why Anticorruption Reforms Fail—Systemic Corruption as a Collective Action Problem. Governance, v. 26, n. 3, p. 449-471, 2013.

PETER, Fabienne. Political Legitimacy. In: ZALTA, Edward N. (ed.). The Stanford Encyclopedia of Philosophy. 2017. Available at: https://plato.stanford.edu/archives/sum2017/entries/legitimacy/.

POGGE, Thomas. World Poverty and Human Rights. 2. ed. Cambridge: Polity Press, 2008.

PRADO, Mariana Mota; CARSON, Lindsay. Brazilian Anti-Corruption Legislation and Its Enforcement: Potential Lessons for Institutional Design. Journal of Self-Governance and Management Economics, v. 4, n. 1, 2016. 
PRADO, Mariana Mota; CORNELIUS, Eduardo. Institutional Multiplicity and the Fight Against Corruption: A Research Agenda for the Brazilian Accountability Network. Revista Direito GV, v. 16, n. 3, e1974, 2020. https: / / doi.org/10.1590/2317-6172201974

PRADO, Mariana Mota; MACHADO, Marta Rodriguez. Using Criminal Law to Fight Corruption: The Potential, Risks and Limitations of Operation Car Wash (Lava Jato). American Journal of Comparative Law, forthcoming.

PRADO, Mariana Mota; PIMENTA, Raquel de Mattos. Systemic Corruption and Institutional Multiplicity: Brazilian examples of a Complex Relationship. University of Toronto Law Journal, forthcoming.

QUAH, Jon S. T. Controlling Corruption in City-States: A Comparative Study of Hong Kong and Singapore. Crime, Law \& Social Change, v. 22, p. 391-414, 1995.

ROSE-ACKERMAN, Susan. Corruption and Government: Causes, Consequences, and Reform. New York: Cambridge University Press, 1999.

ROSE-ACKERMAN, Susan R.; PALIFKA, Bonnie J. Corruption and Government: Causes, Consequences, and Reform. 2. ed. New York: Cambridge University Press, 2016.

ROTBERG, Robert I. The Corruption Cure: How Citizens and Leaders Can Combat Graft. Princeton: Princeton University Press, 2017.

ROTHSTEIN, Bo. Controlling Corruption:The Social Contract Approach. New York: Oxford University Press, 2021.

ROTHSTEIN, Bo. Fighting Systemic Corruption:The Indirect Strategy. Daedalus, v. 147, n. 3, p. 35-49, 2018.

STEPHENSON, Matthew C. Corruption as a Self-Reinforcing Trap: Implications for Reform Strategy. The World Bank Research Observer, v. 35, n. 2, p. 192-226, 2020.

TAYLOR, Mathew M. Getting to Accountability: A Framework for Planning \& Implementing Anticorruption Strategies. Daedalus, v. 147, n. 3, p. 63-82, 2018.

TUSHNET, Mark. Institutions Supporting Constitutional Democracy: Some Thoughts about AntiCorruption (and Other) Agencies. Singapore Journal of Legal Studies, p. 440-455, 2019.

UK DEPARTMENT FOR INTERNATIONAL DEVELOPMENT. Why Corruption Matters: Understanding Causes, Effects and How to Address Them. Evidence Paper on Corruption. London: DFID, 2015. 
WOLF, Mark L. The World Needs an International Anti-Corruption Court. Daedalus, v. 147, n. 3, p. 144-156, 2018.

International Covenant on Civil and Political Rights, G.A. res. 2200A (XXI), 21 U.N. GAOR Supp. (No. 16) at 52, U.N. Doc. A/6316 (1966), 999 U.N.T.S. 171, in force March 23, 1976.

United Nations Convention against Corruption, 2349 U.N.T.S. 41, in force 14 December 2005.

\section{HOW TO QUOTE THIS ARTICLE:}

DAVIS, Kevin E. Anti-corruption Law and Systemic Corruption: The Role of Direct Responses. Revista Direito GV, São Paulo, v. 17, n. 2, maio/ago. 2021, e2129. https://doi.org/10.1590/23176172202129
Kevin E. Davis

Beller Family Professor of Business LaW, New York UNIVERSITY SCHOOL OF LAW. daviskamercury.law.nyu.edu 